\title{
AN UNINTENDED FUTURE
}

\author{
The next great threat.
}

\section{BY TRISTAN SCOTT}

C 7 here's another one! That's five fisheyes. I win." The croaking voice of old Mr Duvelle mocked his equally seasoned friend as they looked out of the window of the geriatric ward. He was referring to a man outside whose eyes had regressed into an earlier form, resembling the 'pin-hole' eyes of some fish.

Mr Higgins lifted his cane with a liverspotted hand, and stabbed at a hairy fellow who was shuffling down the street on his knuckles. "Ah darn-it," he wheezed through his oxygen mask, "another monkey-boy and I would have won. Five seconds too late."

"Five decades too late," Sullivan thought to himself as he overheard the two men's conversation from a few feet away. He too looked out at the extensive array of genetic regressions that passed by: a woman with a tail, a man without an opposable thumb. If these kinds of aberrations were the worst of it, it would not have been so disastrous, but at least half of the regressions were lethal, and that number got worse with each generation.

"It was a simpler time," Mr Duvelle continued to Mr Higgins's affirming grunts. "All we had was that whole climate-change fiasco."

"And look how we fixed that!" Mr Higgins chimed in. "But kids these days, they don't know a thing about banding together for a common cause. Now they have this ... induced ... what do they call it again?"

"Huh?" the partially deaf Mr Duvelle leaned closer, straining to hear his friend.

He pointed a gaunt hand at the people outside and shouted: "What do they call this again?"

"Malform."

They nodded together as Mr Higgins mumbled, "Yes, induced malform evolution."

"My granddaughter, I don't even know if we are related," said Pastor Kane, a man who had aged well, with only fine lines on his dark skin. "She is not of my blood!" He continued to preach to his small congregation of three elderly women across the room, who were fanning themselves. "We thought we knew what we were doing! And for all our improving, look at us now."

"What was the difference again?" asked Mr Duvelle loudly. "That reporter, what did she say the difference for a new species was? You know, the pretty one with the nice teeth."

“0.004\%," Mr Higgins said before he took another deep gasp of oxygen.

“That's it. 0.004\%." Mr Duvelle's head bobbed on his thin neck like a vulture. "That's the difference between a Neanderthal and us. The difference between us and them."

If only the difference was that small, Sullivan silently wished to himself. It is closer

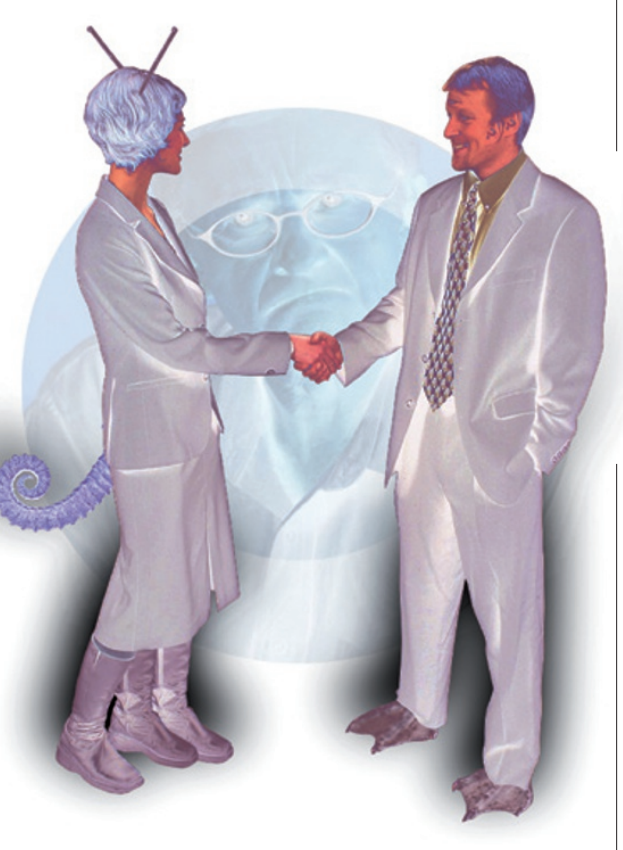

to $1 \%$ in really bad cases. Those ones aren't human any more.

He stared out of the window at a world he did not recognize. It had become a fad after companies commercialized equipment that could easily replace genes, especially the ones that nature never gave you: a year-round tan, blue eyes, a better metabolism. The technology was originally intended to cure diseases, and cure them it did, but eventually it filtered down to be used for what the popular media called 'genetic tattoos'.

It had seemed harmless at first, but over time, much like the slow, silent accumulation of greenhouse gases, it built. A change to a gene here, a deletion there, a little bit left in then passed on to the next generation, then more changes added to that. The changes were cumulative and, before they knew it, the

$\rightarrow$ NATURE.COM

Follow Futures: @NatureFutures

f go.nature.com/mtoodm visible signs started appearing.

'Smog', it was called. Genetic pollution.

"We should not have been meddling," the pastor announced again. "And now - can it be fixed?"

Sullivan wasn't sure if it could, once you have mixed water and jelly, it is hard to separate them. Now it was as if they had mixed hundreds of flavours together and had left them to set for far too long. Natural genes had become dependent on the artificial ones. If they removed the one, the other would be affected. It was incredibly difficult, if not impossible, to tease apart the extensive networks that had become so intricately linked. He scooped up a bit of jelly from his tray and sucked it into his toothless mouth.

"Time to take a sample, Doctor Sullivan," said a young nurse with pseudo-gills along her neck.

He lifted up his sleeve and exposed a thin arm riddled with tiny puncture scars. The nurse placed a thin, silver canister on his arm and with a clipping sound another lump of tissue was excised. She put a plaster on the wound, and then left to prepare the sample. His arms looked no different from those of everyone else in the ward. All of them had hundreds of star-shaped scars, an indication of as many failed experiments.

"Lord knows we are the last of the pure ones," the pastor preached, and the three woman sounded 'Amens' to his sermon. "We are the unedited!" He cast an outstretched finger to the window. "And we are their salvation!"

Sullivan had heard enough. He stood up slowly and reinserted his dentures. The stinging of his arm was a piercing reminder of the work he had yet to achieve, as he shuffled through the hospital. He donned his lab coat, which felt as heavy as the guilt that would not let him rest. He looked up at his old award - the engraved image of Alfred Nobel seemed purposefully turned away, as if shunning him. It was, however, for the same reason that he had received the award, that humanity now faced its next, great threat.

He took a dispirited look at the sample taken from him, and gazed along the rows of tubes containing a hundred others. It was a vain hope, but somehow he had to figure out an answer: how do you backtrack up the evolutionary tree?

Tristan Scott is a PhD student at the University of the Witwatersrand in the field of therapeutic RNA interference. His first fiction novel, Vertical City, has been accepted for publication. 